\title{
Gender Bias in Nordic Vocational Education
}

\section{Anja Heikkinen}

The topic of vocational education and gender has not been of high interest in Nordic countries during last years. On the one hand, the focus has moved to issues like the knowledge society and the competitiveness of individuals and industry in the globalising economy, on the other hand, the strengthening feminist and post-modernist discourses about cultural construction of gender have had marginal interest in vocational education. The article aims at showing that there are historical, anthropological, sociological, philosophical and educational studies, which could revitalise research on vocational education and gender, proceeding from the previous phase, when the focus was on sex-segregation in the labour market and education system. In the beginning of the article, vocational education in the Nordic countries is characterised from the sex-gender perspective, with special focus on Finland. After this, some examples from efforts to overcome and to explain the gender bias are described and deficiencies are discussed. Thirdly, a "cultural approach" for discussing gender bias is suggested. In the closing section, the possibilities of de-gendering vocational education are questioned. The main message of the article is that in order to revitalise research on vocational education and gender, we need to reflect them in a wider cultural context and include the perspectives of both sexes or genders (or the whole sexual and gender order) in our analyses.

\section{Introduction}

Discussions and research on education and gender have been weak in the Nordic countries during the last years, at least in vocational education. Rapid and thorough changes in economy and politics, accompanied with radical changes in educational policies and major reforms, have moved the focus to issues like the making of the information society, and the promotion of competitiveness of individuals and industry in the globalizing economy. In the previous phase, discussions on vocational education and gender were much centred on promoting women to enter male-dominated branches in education as well as on strengthening the occupational and educational status of female-dominated branches in the 
labour market and in the educational system. The marginalisation of the issues of VET and gender has also been promoted by the strengthening of feminist and post-modernist discourses during the 1990s, which turned the focus to the cultural construction and performance of gender, having marginal interest in vocational education. However, there seems to be signs of emerging new discussions with new perspectives on education and gender. In this article, I wish to show that from the yet fragmented studies in historical, anthropological, sociological, philosophical and educational research it would be possible to develop new approaches to vocational education and gender, which could bring the issue closer to the actual concerns of practitioners and policy makers. To my mind, the two main novelties in such approaches would be, firstly, that the sex or gender bias in vocational education is reflected in its relation to a wider cultural and industrial context, where it is embedded and, secondly, that sex and gender are no longer analysed without reference to both sexes or genders (or to the whole sexual and gender order).

In the following sections, first a short characterisation of some typical features of vocational education in the Nordic countries is given from a sex-gender perspective. For pragmatic reasons, these will primarily be represented by Finland. Although there are differences between the Nordic countries, I believe this is acceptable in this context of developing comparative views about the gendered features of European vocational education. Secondly, some examples from the efforts to overcome and to explain the gender bias are described and their problems and deficiencies are discussed. Thirdly, a "cultural approach» to discussing gender bias is suggested. In the closing section, speculations of possibilities of de-gendering vocational education are made.

\section{Facts from gender bias in Nordic VET}

The educational systems of the Nordic countries have for long shared a number of basic principles also in vocational education (VET), for example, the promotion of equality of opportunity in education, working life and public co-ordination, in financing and in the provision of education and teacher training. Since the 1970s, all Nordic countries have considered themselves forerunners in their policies of democratic education, providing publicly funded, free and universal educational opportunities for all. However, especially in VET, their institutions and arrangements have developed quite differently, and still during the 1980s, the countries had rather diverging tendencies in their VET policies. (http://www.nbe.fi/).

Between the 1970s and 1990s, Sweden developed its system of comprehensive upper secondary education (gymnasieskola), which included vocationally oriented study lines and a network of separate labour market training centres providing specialised training for industry. At higher education, the vocationally 
oriented higher institutes became secondary compared with universities. In Denmark, the tradition of apprenticeship training in a specific «dual system» has been strongest and vocational education most separate from academic and university education. Norwegian VET has developed into a model between the Danish and Swedish ones. During the 1990s, however, initial VET started to become integrated into comprehensive upper secondary school through (pre-)vocational lines, consisting of a school-based and a work-based component. The former specialised higher institutes of VET have become amalgamated into colleges of higher education, but separate from academic and university education. Finland has created the widest distinctive, school-based, hierarchically progressing VET system among the Nordic countries. It has aimed at offering education in almost all the occupational areas and at providing a genuine progression route besides academic studies for the whole age group.

During the 1990s, the popularity of academic education has been one of the driving forces for reforming VET in the Nordic countries (Denmark still being an exception), as in most other European countries. Another challenge for reforms was caused by the gradual transformation of VET and VET policy into part of the totality of educational system and educational policy, which separated both administration and planning of VET and VET institutions from industrial policies and practises. As a consequence, in all Nordic VET reforms, the following features can be distinguished:

* the development of a national educational service system, which is, instead of branches, primarily based on levels of education (primary and lower secondary, upper secondary and tertiary), all aiming at economical relevance to both industry and individual learners

* the development of broadly defined, pre-vocational education at upper secondary level, followed by specialised work-based training and by a compensatory work-based training and certification system

* the development of science and technology-based vocational education at tertiary level.

Because of the more developed VET system and the most rapid structural change in social and economic life at the beginning of the 1990s, Finland has probably been most active and thorough in its reform policies. After the economic crisis, caused by the non-controlled liberation of money markets, collapse of trade with Soviet Union and pressure into European integration, Finland was more than the other Nordic countries struck by high unemployment and cuts in public services funding. This was linked to a general shift towards neo-liberalist politics and to the de-construction of the welfare state. Rationalisation, the reduction of human labour and informatization in all sectors of industry proceeded rapidly, working conditions were weakened especially in the female-dominated sectors of private and public services, social welfare and health care. Thus, in 1997, temporary and part-time work already accounted for $70 \%$ of all new work contracts. (Suomalaiset työssä 1998). Perhaps surprisingly, universities 
were exemplary in this process: alongside with the feminisation of academy, permanent positions have been changed into temporary ones, increasing numbers of teachers, researchers and assisting staff are having very short contracts, and have become dependent on external and temporary funding. When proceeding into considerations about the gender bias in Nordic VET, we should not forget the developments in the educational system and policy as a whole. The pedagogical intentions of VET institutes, teachers and students have had to be adjusted to the realities of the years of recession.

One can identify the gender bias in Nordic VET from different perspectives. As for participation in education in general, Nordic women have for long been most active in Europe. The special activity of Finnish women in all kinds of education is indicated also in the latest statistics (http://www.stat.fi, Education at a glance, 1999). Except comprehensive school, women exceed men in every kind of education. Accordingly, about 50\% of the Finnish women under 25 year of age participate in tertiary education, compared with about $35 \%$ of the men. This means that the political aim of $60-65 \%$ of the population attaining a degree in higher education primarily relies on the female population. Although the figures in Sweden are slightly and in Norway and Denmark considerably lower, in general the gender bias in Nordic education means the dominance of women.

However, as can be expected, the main sex differences in VET are between branches. The persistent recruitment of students into male and female dominated branches indicates a gender bias in VET. Because of different classification systems, it is difficult to create a Nordic table on sex differences, but the following figures from Finland are indicative of all Nordic countries.

Table 1. Participation of Finnish women and men in vocational and university education (degree studies) in 1995 (source http://www.stat.fi).

\begin{tabular}{|c|c|c|c|}
\hline \multicolumn{4}{|c|}{ Women and men in vocational and professional education in 1995} \\
\hline Field of education & Students & & \\
\hline (ISCED, including AMKs) & Total & Women, \% & Men, \% \\
\hline Teacher training (14) & 3’300 & 66 & 34 \\
\hline Fine and applied arts $(18,22)$ & 9’300 & 68 & 32 \\
\hline Commerce and social sciences $(30,34)$ & $399^{\prime} 400$ & 62 & 38 \\
\hline Computer programming (46) & $4 ’ 400$ & 14 & 86 \\
\hline Health and medicine (50) & $45^{\prime} 600$ & 88 & 12 \\
\hline Crafts and industry (52) & $40 ’ 900$ & 17 & 83 \\
\hline Engineering (54) & $23 ’ 900$ & 12 & 88 \\
\hline Agriculture and forestry (62) & $8 ' 700$ & 40 & 60 \\
\hline Home economics (66) & 6500 & 94 & 6 \\
\hline Service trades $(78)$ & $17 ’ 100$ & 68 & 32 \\
\hline Others $(70,89)$ & 4'000 & 28 & 72 \\
\hline Total & $203 ’ 100$ & 52 & 48 \\
\hline
\end{tabular}




\begin{tabular}{|c|c|c|c|}
\hline \multicolumn{4}{|c|}{ Women and men in university education in 1995} \\
\hline \multirow[t]{2}{*}{ Field of education (ISCED) } & \multicolumn{3}{|l|}{ Students } \\
\hline & Total & Women, \% & Men, $\%$ \\
\hline Teacher education (14) & $18^{\prime} 200$ & 77 & 23 \\
\hline Humanities, theology, arts $(18,22,26)$ & $24{ }^{\prime} 500$ & 71 & 29 \\
\hline Business administration, economics, soci & & & \\
\hline and behavioural sciences, law $(30,34,38)$ & $322^{\prime} 800$ & 53 & 47 \\
\hline Natural sciences, mathematics, & & & \\
\hline and computer science $(42,46)$ & $20 ’ 700$ & 35 & 65 \\
\hline Medicine (50) & 9'800 & 69 & 31 \\
\hline Engineering (54) & $21^{\prime} 700$ & 18 & 82 \\
\hline Agriculture, forestry (62) & 3'600 & 53 & 47 \\
\hline Others $(58,66,89)$ & $2{ }^{\prime} 000$ & 45 & 55 \\
\hline Total & $1333^{\prime} 300$ & 52 & 48 \\
\hline
\end{tabular}

Note 1. Finnish population is about 5 millions.

Note 2. "AMK" stands for "ammattikorkeakoulu", vocational higher institute or polytechnics, which were launched in Finland at the beginning of the 1990s and which nowadays recruit about half of the vocational students. The official classification of the institutes and branches has been transforming since 1997, but concerning gender bias, the figures are correct enough.

It can be seen from the tables that in VET institutes, women dominate the home economics and service trade branch - consisting of catering, food and cleaning services - and the health and medicine branch. A closer look would reveal a similar situation in social services, especially in day-care. The male domination is greatest in engineering, computer programming and in crafts and industry - especially in transport and car mechanics, electrical technology, construction and metal industry. A more detailed description would show that sex polarisation is strongest at the lower levels of VET, where students primarily enter directly from comprehensive school. In AMKs, where students enter mainly from upper secondary school or have previous educational or occupational experience, polarisation is not so strong. When compared with statistics from previous years and with available information from recent years, the figures show very slight decrease in sex polarisation, except in computer programming/information technology, where it has increased (e.g. Heikkinen, 1995a).

As has been obvious for a long time, sex differences are smallest at highest levels of education. In universities, the most female-dominated fields are teacher education - especially primary school and kindergarten teacher education - and humanities (where a large number of students study languages and enter teaching positions). Having a closer look, the strongest female domination would be found hidden under medicine, where health/nursing science constitutes an independent field. The most male-dominated academic fields are engineering and computer science/information technology. Again, more detailed figures would show that particularly in mathematics and chemistry the sex difference is smaller than it seems in the table. When comparing the university figures with those from a few years ago, it seems that polarisation has increased in the most female and male dominated fields. 
Because of its growing importance, sex differences should also be analysed in adult education. Although there may be differences between the Nordic countries in the provision of VET for adults, the following table from Finland gives a rough picture of the role of VET in formal (institutional) adult education.

Table 2. Distribution of formal adult education.

\begin{tabular}{|c|c|c|}
\hline & Vocational $(62 \%)$ & General/academic (38\%) \\
\hline $\begin{array}{l}\text { Certificate oriented } \\
\text { vocational \& general } \\
(25 \%)\end{array}$ & $\begin{array}{l}\text { *amk-degrees } \\
{ }^{*} \text { apprenticeships } \\
{ }^{*} \text { employment training } \\
\text { *vocational diplomas } \\
{ }^{*} \text { open university }\end{array}$ & $\begin{array}{l}{ }^{*} \text { comprehensive school } \\
\text { *upper secondary }\end{array}$ \\
\hline $\begin{array}{l}\text { Further VET and «liberal» } \\
\text { adult education } \\
(75 \%)\end{array}$ & $\begin{array}{l}\text { *employment training } \\
\text { *further and supplementary } \\
\text { VET } \\
\text { *open university } \\
\text { *continuing university } \\
\text { education }\end{array}$ & $\begin{array}{l}\text { *general studies } \\
{ }^{*} \text { leisure and self-develop- } \\
\text { ment studies } \\
{ }^{*} \text { social studies }\end{array}$ \\
\hline
\end{tabular}

Generally, like in initial vocational and academic education, the gender bias in adult education means the dominance of women. During 1995, about 50\% of all 18-64-year-olds participated in formal adult education, the majority of them being women (http://www.nbe.fi/; http://www.stat.fi/) From the over million participants in work or occupation oriented adult education, women accounted for 55\%. However, when looking at the subjects, one finds male-dominated areas of computer science, engineering, construction and management and female-dominated areas of commerce, social welfare and health care. The real consumers of liberal adult education are women, who account for over $70 \%$ of the general and leisure oriented adult education, primarily in fine and applied arts, in physical education and in languages. Findings from open university and from that of the third age also indicate that as life-long learners women have until now more than men been interested in education for reasons of personal development and without direct benefit in work.

The praised Nordic politics of equality of opportunity becomes less convincing when we look at the large area of informal adult education in staff and personnel training. It has been rather controversial in terms of sex. On the one hand, because the public sector has for long been more active in training its staff, which are largely female, employees have started to conceive training as self-evident rather than as a privilege. However, because of the reductions in the welfare services and the worsening of working conditions in the public sector, women are losing their previous lead in the quality and quantity of continuing education. On the other hand, primarily in the private sector and in big enterprises, staff training has been highly polarised. Off-the-job and long-term training, 
which also provides personal career options, is arranged for employees and managers at higher level and narrow on-the-job training is arranged for the shop floor workers. Because in both the public and private sectors women still occupy, despite their level of education, lower hierarchical positions, men benefit most from such forms of staff training that are crucial to career progress.

\section{Efforts to overcome and to explain gender bias}

In this section, I shall first characterise some practical efforts to overcome gender bias in Nordic VET, and then comment on the endeavours to explain it. To start with, I will again remind that at political level the Nordic countries have for long been committed to combating gender bias in education or work. The promotion of equality between men and women belongs to the aims of education. The socio-political legislation and building of welfare societies have supported individuals to make independent choices regarding their education, occupation, partnership and family. There have also been explicit efforts to overcome the gender bias in education and work during the 1980s and 1990s. For example, there was a wide Nordic programme «Avaa-Bryt» («Open») for promoting girls and women to learn natural sciences and technology and to enter male-dominated technical occupations. Some changes took place during and immediately after the programme, but soon the bias was back and even worse than before. Attempts have also been made to encourage men by quotas to enter female-dominated branches, e.g. primary school teacher education. Although such efforts may have contributed to raising interest in the gender bias in education, they have also shown how difficult it is to challenge it by isolated action programmes. It remains typical that the men from female-dominated fields of education either enter managerial positions or change their occupation and that the women from male-dominated fields enter planning or human resource development jobs instead of production and management.

In the wider society, the legislation on promoting equality of women and men has increased the sex balance in state and municipal political and administrative organs in all Nordic countries, which may have effects on the rest of the societal and industrial life. However, one persistent criterion for sex differences seems to be the salary: despite the level of education or demands of work, men are earning more than women. Large projects have been set up for developing job-evaluation and work contract systems, which would promote equal pay in all branches with comparable educational and qualification demands. The differences still persist. On the contrary, especially in Finland during the recession and high unemployment, the pressure to lower the salaries in both the private and public services increased in comparison with the male-dominated occupations protected by strong unions in industry. Furthermore, in recent years and alongside with the boom in information technology and globalisation of businesses, alternative salary and reward systems have been adopted, primarily for men, which have still increased the income disparities. Under the dominance of a neo- 
liberalist policy, it seems that the practices and principles of leading companies are becoming adopted in all sectors of industry. Whilst these companies have been the headquarters of the male-dominated educational fields and occupations, we may question the alternative nature of female-dominated VET or occupations. Are not the values in all education and work converging into economic efficiency and organisational and individual competitiveness?

Secondly, besides practical efforts to overcome gender bias in education and work, there have been attempts to explain the situation in the Nordic countries. This has primarily been done by feminist or women researchers, as they call themselves; gender bias has marginally been studied by men or from a male perspective. This is also due to the fact that in the Nordic countries feminist researchers have efficiently utilised the opportunities of legislation on equality between men and women and established study programmes, chairs, research centres and institutes for women studies in most universities. It is clear that these short characterisations of their contribution to explaining gender bias in VET are very superficial and fail to do full justice to them (cf. authors like Anttalainen, Anttonen, Henriksson, Kinnunen, Korvajärvi, Nummenmaa, Nätkin, Rantalaiho, Hirdman, Melby, Waerness).

During the 1970s and 1980s, numerous empirical sociological studies were carried out of gender segregation in the labour market, in education and in school-to-work transitions of girls and women. Typically, family background and attitudes of fathers (rather than mothers) were conceived as explanatory factors for educational and occupational choice. It was important to show that there was no essential, biological basis for the sex differences. Later the proponents of this strand turned their focus to female-dominated occupations and work-place practices. Explanations for women's recruitment and remaining in lower whitecollar jobs and in lower positions in work hierarchies were explained by gendered and gendering organisational practices. Such explanations have typically been extensions of universal sociological theories of patriarchy and gender contract. According to these, gender segregation and women's position were interpreted as outcomes of a global tendency to maintain a patriarchal order in society, where women are subordinate and servile to men in partnership, in family, in work, in economy and in politics. In the Nordic countries, the concept of gender contract has been particularly important. It refers to an informal collective agreement about the division of work and power between the male-dominated productive sphere and female-dominated reproductive sphere. It is assumed that the gender contract has promoted the differentiation of male and female rationality, morals and mentality, social construction of masculinity and femininity.

In the realms of education and work, women researchers have contributed by making visible women's ways of acting, thinking and feeling and by showing their genuine feminine characteristics. This research has encouraged women to struggle for social recognition of female-dominated work and education as exemplary of femininity. Quite often femininity is also described, not only as hav- 
ing "comparable worth», but as being ethically superior to masculinity. Therefore, if the hegemony of masculinity prevails in the male-dominated branches of education and work and they fail to transform into a more feminine direction, it is evident that both sexes continue their gender biased educational and occupational choices, based on their own rationality. In recent years, the mainstream women research has moved towards a postmodernist and culturalist direction. Although it is premature to evaluate its contributions to research on education and work, issues of vocational education seem to be of marginal interest in this strand.

However, there already exists much relevant sociological, even some historical or anthropological research in the Nordic countries, which has not sufficiently been utilised in reflections about gender bias in VET. In this respect, one of the crucial findings of feminist research is that the gender bias is an outcome of the emergence of the Nordic welfare state. According to the arguments, it was the alliance of women and the state that made possible the public recognition of women's shared interests and competencies, which centred on caring as an indispensable basis of social and industrial life. However, an elaboration of previous research perspectives as well as new data and materials for research may also be needed. Particularly in analysing the role of the state in promoting the emergence of gender bias in education and work, it may not be enough just to look at the welfare society and caring work. Other sectors of society and industry and their relation to the state should also be considered.

\section{Gender and VET: a cultural perspective}

In order to deepen the understanding of the gender bias in VET and to overcome the opposing views of VET, either as an outcome of general gendering processes or as a gendering institution itself, new methodological approaches may be needed. As one alternative, I propose a cultural approach, which would integrate and synthesise various fields of research into new, more holistic and internally complex conceptual and explanatory models. In short, a «cultural approach» would be constituted by parallel or intertwined discussions and encounters of historical, philosophical, sociological and comparative inquiries. This definition needs specification, of course: not all kinds of inquiries are relevant to cultural research on VET. However, some examples are suggested in the following. As can be seen, although I think that the different elements should be intertwined, I find the historical inquiry most constitutive for any concrete effort to develop a cultural approach, not least because our knowledge and understanding of the formation of VET is so fragmented and lacking in most countries. The importance of a historical approach is also linked to my pre-conception of culture (cf. Heikkinen, 1997; Heikkinen, 1999) as a static, dynamic and generative phenomenon: it is the state of, the making and production of and the creation and generation of meanings, interpretations, values and ethos and their objectification. These aspects of culture materialise at the levels 
of persons, communities/collectives, societies/nation-states, trans-national entities/globe. In order to stress the dynamic and generative aspects of culture, important to educational research, I also speak about culture as a project and use the expression «cultural project».

Furthermore, in our time we primarily conceive education in the framework of a nation-state and it is this view that is most challenged by the recent developments in economy, politics, industry and VET. Therefore, it seems reasonable to start reflections from the cultural level of nation-states and from historical interpretations about the emergence of VET in the context of nation-state formation. Even if such historical inquiry would rather be a kind of genealogy in the Foucaltian sense than a pure exercise of historical science itself, new ways of collaboration with historical research would also be needed. The approach I am proposing implies that the gender bias in VET should be analysed in the context of wider cultural projects, not as a separate phenomenon. In the following, I shall tentatively characterise some important aspects and steps in this process in the Nordic countries.

One prerequisite for the construction and success of most cultural projects, which were involved in nation-building and constitution of the nation-state in the Nordic countries, has been the recognition of both sexes in industrial ${ }^{1}$ and societal life and activities. This indicates that they did not share the central-European perceptions of publicity and privacy or they were marginally influential (cf. Frevert, 1995, Darmann et al., 1998). In Finland, during the crucial period of nation building, from the middle of the 19th century until about the 1930s, the productive and reproductive activities and spheres were closely connected in the "total social division of work». They were shared by both sexes, they were publicly visible and recognized - though not necessarily equally valued. In spite of the differences in concrete tasks, for example «occupation» was for long conceived as a collective industry or trade in a community, household or family rather than as a property of an individual. However, since the ownership of an estate, office, craft-workshop or factory had increasingly become legally (and later conventionally) represented by men and inherited by the eldest sons, women's societal and economic role is less visible in official documents; and surely it was more dependent also in practice.

Many historical, anthropological and folkloristic studies support the arguments for the importance of the reciprocal productive positions and androgynic features of the sexes in the Finnish agrarian culture (e.g. Apo, 1995; Peltonen, 1992, 1999; Ollila, 1993; Löfström, 1999). A contribution to the household, family and community, to the unit of «the reproduction of the means of livelihood» (to use the expression from S. Narotzsky, 1996), was decisive for the social participation of both men and women. The special reproductive role of women as child-bearers was recognized, but subsumed within the totality of the unit. For example, M. Peltonen (1999) argues that the reasons for sexual division of work were primarily, also symbolically, spatial. To continue his thought, the 
symbolic meanings of spaces can be explained on the basis of their links to the popular religious view of three worlds, which human beings were believed to be inhabiting. The middle-world was the visible, corporeal sphere of natural existence, the under-world and over-world were spheres of invisible and supra-natural, which could be experienced in emotional, spiritual acts. Like all human events in the middle world, sexuality and sexual reproduction were also connected to the other worlds, materially in certain environments and objects. Although there were also pragmatic and economic reasons, such beliefs supported definitions of spaces, which could be shared by men and women, (the house, the yard, the fields, waters, parts of forests) or where work was less suitable for women (roads, forests) or for men (kitchen, cowshed), but which both sexes could enter if necessary. For understanding gender-bias in VET, the recognition of the symbolic meaning of space in constructing gender is important. It also challenges some conclusions based on observations of sex differences in work behaviour in more prosperous farms in the 19th century. The stronger separation of male and female spheres into the house and the surroundings does not necessarily indicate essential sex differences in work tasks themselves, nor a more eager adoption of a bourgeois culture or protestant religion. It may also be a demonstration by the household to others that it can afford to allocate symbolic space in an optimal way for both sexes, but especially for women.

Another feature of the Finnish agrarian cultural heritage, raised by J. Löfström (1999), is interesting: in order to become a man or a woman, it was most important for boys and girls to achieve the level of adult man or woman in work performance, instead of performance in sexuality, which was the case in many other cultures. As for the formation of the gender bias in VET, it is important to see how central work and work performances and the educational practices promoting work-related growth into participation in adult life have been to social construction of gender.

In order to conceive the development of gender bias during the crucial period of nation-formation, it has to be located in the wider context of inter-linked projects of Finland, industry and VET (cf. Heikkinen, 1998, Heikkinen et al., 1999). In 1809, after being separated from Sweden and having become an autonomous grand duchy of Russia, Finland had to re-build or create its own systems and practices of administration, industry and education. The emerging programmes of the existing and ascending influential groups in society - the followers of the Swedish-speaking military and administrative elite, the clergy, the big farmers, manufacturers and merchants, but increasingly also groups of Finnish-speaking intelligentsia, small farmers and civil servants - were twofold. On the one hand, the promotion of industrial expertise among civil servants and leaders of industry was crucial to national prosperity and successful export industry. On the other hand, it was equally important to support the vast majority of Finnish-speaking population, who lived from agriculture, which also provided raw materials and cheap labour for industry. Agrarian households were small, ge- 
ographically scattered and self-sustaining. Therefore, the first of these programmes focused on developing state-supported full-time institutes for the civil servants and leaders of industry in most important branches like seafaring, agriculture, mining, textile and wood-processing industry, commerce and forestry. The second programme focused on developing a state-supported network of advisers and ambulating or part-time schools in farming, animal husbandry, home industry, home economics etc. in the rural areas. The programmes materialized the emerging cultural projects of nation-building, industry and education. For recognizing their difference from the central-European projects, it is important to realize that, because of the marginality and cultural distance of craft from large-scale industry, the Sunday and Crafts schools, established for apprentices, could not develop into any examples of vocational education. However, in relation to the gender bias in VET, it is remarkable that the promotion of agrarian industries and the establishment of craft schools both targeted whole communities or households, not separately men or women, even if there were sex differences in participation.

Another important factor in the further formation of the gender bias in VET, was the sharpening struggle between and within the cultural projects. The divisions between ordinary men and women - small farmers and landless people and bourgeois men and women, internally split into Fennoman and Svekoman camps - became influential by the end of the 19th century. VET became one platform for the struggles (cf. Henriksson, 1996, 1998; Heikkinen, 1996; Tulkki, 1995). However, the process was modified because of the growing political oppression of Russia during the 1880s - 1910s, since the defenders of Finnish autonomy centred their efforts largely on promoting Finnish industry and economy. For this, women and their education were of crucial importance and had to be recognized. This is important for comprehending that the commitment of the state - or more generally the public sector - to characteristic solutions of Finnish VET was holistic and included both women and men. It may also refer to reasons, which have differentiated the role of the state in the Nordic countries with regard to the formation of the gender bias in VET.

One of the basic struggles related to the gender bias in VET, which continued until the stabilization of the welfare-state in the 1960s-70s, was about nursing education. The aims and strategies of (Swedish-speaking) bourgeois women, who in the turn of the 20th century were searching for female alternatives in occupational work, were diverging from the realities and aims of ordinary women in the field. For them, however, the ideals of bourgeois women represented the aspired bourgeois way of life, and therefore were accepted as conditions for their own social ascendance. In the core of the struggle was the fight of bourgeois women with bourgeois male medical doctors about recognition of nursing as an independent occupation, requiring its own education, controlled by nurses themselves. As L. Henriksson (1996) has shown, the dominant strategy in this finally victorious struggle consisted of belittling and ignorance of the heritage of 
women's knowledge and skills as «domestic qualifications». Later this strategy lead into the development of a genuine (feminine) science as the basis of nurse expertise.

The main struggle about male VET is commonly (e.g. Tulkki, 1995) described as the one between the Fennomans and Svekomans about the ownership and control of engineer occupation and education. The big export industry was a powerful player in the Finnish economy and politics. For the rising Fennomans, in order to compete with the established industrial elite, represented by Swedish-speaking male engineers, it was important to promote the expansion and upgrading of the level of school-based and state-supported technological education. The big difference as compared with the struggle of nursing was, of course, that it was not between the sexes. What most commentators do not recognize, however, is that (as in the case of nursing) the struggle of the Fennomans implied a strategy of belittling and neglect of the heritage of the "domestic skills and knowledge» in the agrarian, industrial or crafts work practices. Like in nursing, the ideals of higher technical occupations and education increasingly became exemplary also for the occupations and VET among skilled workers (cf. Heikkinen, 1995b). After the Finnish independence in 1917, and especially after the World War II, commitment to industrial progress and admiration of technology became one characteristic of Finnish VET.

In order to draw conclusions about the formation of the gender bias in VET, the struggles about nursing and engineering should, however, be understood in the wider context of competing cultural projects during the 1850s - 1910s. In the vast area of agricultural industries - farming, animal husbandry, textile and garment production, food processing, wood-work and construction, fishing and forestry - skills were learnt in informal, apprenticeship kinds of ways, partly supported by advisers and a few (though most numerous in absolute figures) permanent and ambulating schools, especially for farming, home industry and home economics (or rather for "the mistresses of farms»). In this area, gender was explicitly addressed only in the initiatives of bourgeois women - supported by bourgeois men. They started to establish other kinds of schools for home economics and vocational schools for girls, the first aiming also at educating decent housewives and mistresses, whereas both aimed at preparing servants and workers in cooking, sewing and household.

These initiatives become comprehensible in the context of the social problems of landless people and poverty, which were growing by the end of the 19th century. Women in particular made extensive efforts to enter industry and services. The land reforms around the 1920s, as well as settlement politics during the World War II, attempted to moderate the pressure and to prolong the dominance of agriculture as a means of livelihood. However, the social-political function of VET became ever more important. In the transformation process of VET, the representatives of «domestic (agrarian) qualifications» and of informal ways of education were not able to articulate their aims and strategies. The de- 
fenders of the project of agrarian Finland with its specific principles of welfare could only resist the development, e.g. by developing vocationally oriented continuation classes for rural primary schools and by slowing down the decline of agricultural education. More important is that the drifting of women into towns to look for work, promoted - besides girls' vocational schools - the establishment of a network of commercial schools, which supported the creation of low white-collar office and retail occupations for women. In a wider view, the gradual democratization of economy, society and education, the development and stabilizing of the Finnish-speaking industry since the 1920s, accelerated by the political consensus during war-time, diminished the gap between bourgeoisie and ordinary people: occupational and educational ideals started to converge.

Although the cultural projects related to VET differ between the Nordic countries, analyses similar to those made in Finland could also be made of the formation of the gender bias in VET. In the thorough transformation and expansion of VET in Finland during the 1950s - 1970s, it was a co-constituent of a wider industrial and societal change, which can also be called a cultural project of modernization. Backed by the consensus of the projects of agrarian, industrial and welfare-Finland, it was deliberately cutting the roots to the previous forms of life and work. However, the meanings given to work and VET by ordinary people could hardly be transformed so easily. (cf. Heikkinen et al., 1996; Kortteinen, 1992). The gender bias in VET, which can still be found in the statistics, was constituted by the incorporation of the efforts of men and women, who tried to negotiate their own personal and collective cultural projects with the rapid changes in industry, economy and education. In the different branches and levels of VET, different strategies were developed when men and women searched for new ways of becoming adults through occupational work. The radical difference as compared with the long-lasted agrarian cultural heritage was that the productive and reproductive work and occupations had separated into their distinct, internally fragmented sectors. Although now both owning their occupations, women had ended into reproduction and service branches and men into management, control and executive work in production.

\section{De-gendering VET?}

The sex differences in work and VET seem to be very persistent in all countries. In this concluding section, I therefore question whether it actually is necessary, desirable or possible to try to reduce them in VET.

Firstly, if the factors effecting the gender bias in VET are largely of a general societal and cultural nature, is there sense in trying to change education, or should the efforts focus elsewhere? The difficulty of proceeding to discuss such issues trans-culturally becomes visible in our languages. How to discuss gender, male, female, masculinity and femininity generally if they do not even have 
equivalent meanings in different languages. For example, in Finnish, the word "sukupuoli» is composed of "suku» - family or (in scientific use) genus - and "puoli» - «half» or «one side of something». Therefore, Finns have to add biological/sexual or social to "sukupuoli» in order to distinguish between sex and gender. There are no equivalents for the words male-female or femininity-masculinity either: the Finnish language uses derivations of «mies» - "man» and «nainen» - «woman», i.e. «miehinen, miehekkyys» - «manly, manliness» and «naisellinen, naisellisuus» - «womanly, womanliness». Proceeding from this, one might claim that it is wrong to interpret the sex differences in VET straightforwardly as gender bias. For example, the sex-differentiated ideals of nurse and engineer may in fact indicate the androgynity of Finnish (or Nordic) VET. They may indicate the continuity of agrarian culture where feelings were secondary compared with the necessities of production and reproduction and where emotional neutrality was respected highly in both male and female work performance and recognized as a sign of occupational expertise. Nurses and engineers may both be exemplary of the commitment of women and men to work as «an escape from dependence and fear of social and emotional rejection», of the recognition of life as «a list of work-achievements», and of the work-performance as «more important than recognition as a person», or even as a "secular religion» (cf. Kortteinen, 1992; Siltala, 1994; Kjellberg, 1994). Nurses and engineers may also both be ideal-typical in their neutrality towards economic and political contradictions, based on neutral technology of engineering or nursing. Both represent an ideal of ownership of occupation, a mutation from ownership of a farm or an independent craft. Both carry some traditional elements of womanliness and manliness, but in their separate spheres replace the previous reciprocal productive roles by "productive manliness» and by «reproductive, non-productive womanliness». If in the context of holistic production-reproduction, sex differences in work functioned for the good of the whole form of life, perhaps in the segmented industry concentrating on production, they also function for the good of such a form of life. ${ }^{2}$

Secondly, if we consider VET itself to be a constituent of gender bias in society and industry, what could the de-construction of gendered VET or de-gendering of VET mean? In addressing this question, we cannot avoid discussions about VET as a form of education. According to my understanding, the specificity of VET as educational activity, which distinguishes it from socialization which is the general (sociological) reference in discussions about gender bias - is based on its ethical and normative nature (cf. Heikkinen, 1992; Vogel, 1996). Although not explicitly referring to education, a male philosopher P. Sipilä clarifies my point well. «Contrary to what we easily infer from sociological theories, we are not socialized into gender, because as boys and girls we are being given different names, different clothes and different toys; not because as children of different sexes we are being talked to with different tones and scolded for different reasons; not even because we are encouraged to enter different occupations 
and missions in life. We are socialized (into gender) because at some level of our thinking we believe that all this is right” (Sipilä, 1998, my emphasis). Applying his argument to VET, we could say that the reason why we educate and let ourselves be educated into sexed or gendered roles and identities, is our belief that it is good and just for human beings to have sexed or gendered identities.

If we try to link this reasoning to the first question, we may need to reconsider the relations between sex, gender, education and work. It may have been that emotional neutrality and the construction of gender through work have been functional for our previous forms of life. However, since long ago, the systems of production and reproduction, and the corresponding industries have become separated, and along with their globalization, their connectedness becomes less and less transparent. Similarly, sexuality has lost its existential and reproductive meaning in our lives. As J. Löfström (1999) argues, in this context sexuality has increasingly transformed into a central platform for the construction of gender. Concerning the educational challenges, which this brings to VET, I would like to stress the emotional deficiency of Nordic, or at least Finnish, cultural heritage. Is not the incapacity to work it out collectively, worsened by a continuing decrease in wage labour, becoming visible in our feverish commitment to become the leaders in information technology, to demonstrate our extreme technological expertise and efficiency? Is this not accompanied with increasing signs of emotional suffering among young people and adults, which are often linked to sexuality, education and work? Besides the growing problems of drugs and alcohol also among young people, anorexia and other eating problems have increased dramatically among girls and women. In our collective and individual lives, polarization between extreme performances and total failures in work, social relations, companionship is growing. ${ }^{3}$

Educationists might learn from psycho-historical research about the transformations of a pathological commitment to gender-construction in work or other spheres of life (cf. Siltala, 1994, 1999). Such reflections might help us to rethink the vulnerability, dependency and mortality of human beings, the existential fear we have in facing it and the role of work and sexuality in our existence. (MacInnes, 1998). If we fail to confront the existential and emotional levels, which are linked to sex differences and pathological constructions of gender, formal efforts to reduce gender bias in VET may only support their renewal in new forms. Following P. Sipilä, we might question whether educationists should be interested in developing such holistic ethics, which prioritizes being a human being, rather than being a sexual or gendered creature. If sexuality (and gender) would become more secondary in our lives, it might be more incidental or individual how people combine sexual identifications to work, occupation or VET.

New divisions of work and new conceptions of occupation are emerging in the globalizing economies and industries, supported by information technology, transforming constellations of sex and gender relations in societal and industrial life (cf. Adam, 1998). They are challenging educationists to develop strategies at 
trans-national and trans-cultural levels. This requires the development of new communicative spaces, based on mutual understanding of the historical and cultural layers, which are underpinning the prevailing arrangements (systems) of VET. In order to understand the gender biases in VET, the varieties of the wider cultural projects and transformations in the "total social division of work", including both sexes, should be studied.

\section{Notes}

1 It is difficult to use the word industry in a logical way. When speaking generally of all the different economic activities and branches of production, it includes in my mind also agriculture, craft, services etc. When speaking about differences between branches, it refers to manufacturing industries. I have not been able to solve the problem in this text.

2 In the case of Finland, one should not underestimate the importance of the World War II and the following reconstruction period for maintaining these occupational ideals.

3 In the debates about the Swedish welfare society, a phrase «the country where children are being taken care of, but not loved», has sometimes been used; it has not spread wider, perhaps being too provocative.

\section{References}

Adam, A. (1998). Artificial Knowing. London: Routledge.

Aikuiskoulutustutkimus (1995). Helsinki: Tilastokeskus 1999.

Anttalainen, M.-L. (1986). Sukupuolen mukaan kahtia jakautunet työmarkkinat pohjoismaissa. Helsinki: TANE.

Apo, S. (1995). Naisen väki. Hämeenlinna: Hanki ja jää.

Darmann, I., Mayer, C. \& Wittneben, K. (1998). Krankenpflege als bürgerlicher Frauenberuf. In Rückblick für die Zukunft. Beiträge zur historischen Pflegeforschung. Wien-München-Bern: Wilhelm Maudrich.

de Groot, G. \& Schrover, M. (1995). Women Workers and Technological Change. Bristol: Taylor \& Francis.

Foucault, M. (1990). The Order of Things. London - NY: Routledge.

Frevert, U. (1995). "Mann und Weib, und Weib und Mann". Geschlechter-Differenzen in der Moderne. München: Beck'sche Reihe.

Heikkinen, A. (1992). Ammattikasvatuksen etiikka. In Heikkinen, A. (Ed.), Ammattikasvatus ja sosialisaatio. Tampereen yliopisto.

Heikkinen, A. (1994). The Emergence of the Finnish Idea of Vocational Schooling in Crafts and Industry. In Heikkinen, A. (Ed.), Vocational Education and Culture. European Prospects from History and Life-history. Ammattikasvatussarja 9. Tampereen yliopisto.

Heikkinen, A. (1995a). Risky futures for the daughters of the Nordic welfare-state. In Green, A. \& Bash, L. (Ed.). (1995), World Yearbook of Education. Youth, Education and Work. London: Kogan Page.

Heikkinen, A. (1995b). Lähtökohtia ammattikasvatuksen kulttuuriseen tarkasteluun. Esimerkkinä suomalaisen ammattikasvatuksen muotoutuminen käsityön ja teollisuuden alalla 18401940. Tampereen yliopisto.

Heikkinen, A. (1996). Gendered occupational ideals in Finnish vocational education. In Heikkinen, A. (Ed.) (1996), Gendered history of (vocational) education - European comparisons. Ammattikasvatussarja 14. Tampereen yliopisto.

Heikkinen, A. (1996). Berufsbildung als Faktor des sozialen Wandels in Finnland. In Greinert, W.-D. et al. (Hrsg.), Berufsausbildung und sozialer Wandel. Berlin: BIBB. 
Heikkinen, A. (Ed.) (1996). Gendered history of (vocational) education - European comparisons. Ammattikasvatussarja 14. Tampereen yliopisto.

Heikkinen, A. (1997). How to study apprenticeship comparatively? In Heikkinen, A. \& Sultana, R., Vocational education and apprenticeships in Europe - challenges for research and practice. Tampereen yliopisto.

Heikkinen, A. (1998). Technocracy, Patriotism or Care? Social change and vocational education in Finland. In Sakslind, R. (Ed.), Danning og yrkesutdanning. University of Bergen.

Heikkinen, A., Korkiakangas, M., Kuusisto, L., Nuotio, P. \& Tiilikkala, L. (1999). Elinkeinon edistämisestä koulutuspalvelujen laaduntarkkailuun. Ammattikasvatussarja 20. Tampereen yliopisto.

Henriksson, L. (1996). Occupational politics of health work - women's involvement in creating the foundations of he Finnish welfare state. In Heikkinen, Anja (Ed.), Gendered history of (vocational education) - European comparisons. Ammattikasvatussarja 14. Tampereen yliopisto.

Henriksson, L. (1998). Naisten terveystyö ja ammatillistumisen politiikka. Helsinki: STAKES.

Hentilä, M. (1999). «Pikku myyjätär» - Ammatin naisistuminen ja hygienian tulo myymälään. In Parikka, R. (toim.). Suomalaisen työn historiaa. Helsinki: SKS

Kinnunen, M. \& Korvajärvi, P. (toim.) (1996). Työelämän sukupuolistavat käytännöt. Tampere: Vastapaino.

Kjellberg, S. (1994). Finländsk arbetsetik och Luthers kallelselära. Åbo Akademis förlag.

Kortteinen, M. (1992). Kunnian kentät. Tampere: Vastapaino.

Larrabee, M.J. (1993). An Ethic of Care. NY - London: Routledge.

Löfström, J. (1999). Sukupuoliero agraarikulttuurissa. Helsinki: SKS.

MacInnes, J. (1998). The End of Masculinity. London: Open University Press.

Mjelde, L. (1996). Dinner through text: the advent of domestic science and house-wife ideology in Norwegian education. In Heikkinen, A. (Ed.), Gendered history of (vocational) education - European comparisons. Ammattikasvatussarja 14. Tampereen yliopisto.

Narotzsky, S. (1996). New Directions in Economic Anthropology. London: Pluto Press.

Nummenmaa, A.-R. (1990). Miesten ammatti tytön koulutusvalintana. Tampereen yliopisto.

Nummenmaa, A.-R. \& Vanhalakka-Ruoho, M. (1985). Ammatti, sukupuoli ja työmarkkinat. Tampereen yliopisto.

OECD (1999). Education at a glance.

Ollila, A. (1993). Suomen kotien päivä valkenee... Helsinki: SHS.

Parikka, R. (Ed.) (1999). Suomalaisen työn historiaa. Helsinki: SKS.

Peltonen, M. (1999). Työnjako sosiaalisena tilana - Sukupuolenmukaisesta työnjaosta maataloudessa. In Parikka, R. (Ed.), Suomalaisen työn historiaa. Helsinki: SKS.

Peltonen, M. (1992). Talolliset ja torpparit. Helsinki: SHS.

Rantalaiho, L. (1994). Sukupuolisopimus ja Suomen malli. In Anttonen, A., Henriksson, L. \& Nätkin, R. (eds). Naisten hyvinvointivaltio. Tampere: Vastapaino.

Rommelspacher, B. (1992). Mitmenschlichkeit und Unterwerfung. Frankfurt: Campus.

Siltala, J. (1999). Sosiologinen ja psykologinen minä. In Näre, S. (Ed.), Tunteiden sosiologiaa, osa II. Historiaa ja säätelyä. Helsinki: SKS.

Siltala, J. (1994). Miehen kunnia. Keuruu: Otava.

Sipilä, P. (1998). Sukupuolitettu ihminen. Helsinki: Gaudeamus.

Suomalaiset työssä (1998). Helsinki: Tilastokeskus.

Tallberg, M. (1991). Den sekularä sjuksköterskan i Finland från 1700-talet till den enthetliga utbildningens början 1930. Kuopion yliopisto: Alkuperäistutkimukset 1/1991.

Tulkki, P. (1995). Valtion virka vai teollinen työ. Turku: RUSE.

Vogel, P. (1996). Scheinprobleme in der Erziehungswissenschaft: das Verhältnis von «Erziehung» und «Sozialisation». Zeitschrift für Pädagogik, 4, 1996.

Waerness, K. (1987). On the Rationality of Caring. In Sassoon, A. (Ed.). Women and the State. London. 


\section{Geschlechtsspezifische Unterschiede in der nordischen Berufsbildung}

\section{Zusammenfassung}

Während der letzten Jahre fand das Thema Geschlecht und Berufsbildung in den nordischen Staaten keine grosse Beachtung. Einerseits wurden Themen wie die Wissensgesellschaft oder die individuelle und industrielle Konkurrenzfähigkeit in einer globalisierten Ökonomie fokussiert, andererseits schuf der zunehmende feministische und postmoderne Diskurs über die kulturelle Konstruktion der Geschlechter nur marginale Interessen für die Berufsbildung. Dieser Beitrag hat zum Ziel, auf historische, anthropologische, soziologische, philosophische und pädagogische Studien hinzuweisen, welche die Forschung zu geschlechtsspezifischen Fragen in der Berufsbildung revitalisieren können und aus der früheren Diskussionsphase, als der Fokus auf der Geschlechtersegregation auf dem Arbeitsmarkt und im Bildungssystem lag, weiterführen.

Der erste Teil des Beitrages stellt die Berufsbildung der nordischen Staaten aus der Geschlechterperspektive dar, wobei Finnland besondere Aufmerksamkeit gewidmet wird. Im zweiten Teil werden Anstrengungen beschrieben, die geschlechtsspezifischen Unterschiede zu erklären und zu überwinden. Drittens wird ein kultureller Zugang vorgeschlagen, um die geschlechtsspezifischen Unterschiede diskutieren zu können. Anschliessend wird die Frage nach den Möglichkeiten einer geschlechtsunabhängigen Berufsbildung gestellt. Die Hauptaussage des Beitrages ist, dass das Thema Berufsbildung und Geschlecht bei der Revitalisierung der Forschung in einem breiteren kulturellen Kontext reflektiert werden muss und die Perspektive beider Geschlechter (die gesamte Geschlechterordnung) in die Analysen einbezogen werden muss.

\section{Biais liés au genre au niveau de la formation professionnelle dans les pays nordiques}

\section{Résumé}

La thématique de la formation professionnelle et du genre n'a pas suscité beaucoup d'intérêt dans les pays nordiques ces dernières années. D'une part, l'attention s'est focalisée sur des sujets comme la société du savoir ou la compétitivité des individus et des entreprises dans un environnement en voie de globalisation; d'autre part, les discours féministes et postmodernistes sur la construction culturelle du genre n'ont porté qu'un intérêt marginal à la formation professionnelle.

L'article entend démontrer qu'il existe un ensemble d'études (historiques, anthropologiques, sociologiques, philosophiques et pédagogiques) à même de revitaliser la recherche sur la thématique genre et formation professionnelle en partant de l'étape précédente dans laquelle l'accent était mis sur le rôle de la ségrégation 
sexuelle sur le marché du travail et dans le système éducatif.

L'article commence par examiner les caractéristiques de la formation professionnelle dans la perspective du genre en développant surtout l'exemple de la Finlande. Puis il traite des efforts entrepris pour dépasser et expliquer les préjugés relatifs au genre en relevant aussi leurs limites. Dans une troisième partie, l'article esquisse une approche culturelle de la question du genre avant, en conclusion, de discuter de la possibilité de «dé-gendréfier» («de-gendering») le domaine de la formation professionnelle.

Le message principal de cette contribution est de montrer que la revitalisation de la recherche sur la formation et le genre passe par un déplacement du débat dans un contexte culturel plus large en incluant dans l'analyse le point de vue des deux sexes ou genres (ou tout ce qui est de l'ordre du sexe ou du genre).

\section{Fattori legati all'appartenenza sessuale nell'ambito della formazione professionale nei paesi nordici.}

\section{Riassunto}

Le questioni inerenti il rapporto tra sesso di appartenenza e formazione professionale non hanno suscitato molto interesse nei paesi nordici negli ultimi anni. Da un lato l'attenzione è stata attirata da problemi quali la società della conoscenza e la competitività degli individui e delle aziende in une economia tesa alla globalizzazione, dall'altro lato il rafforzamento del discorso femminista e post-modernista al riguardo delle implicazioni culturali delle questioni legate al sesso di appartenenza sono state di interesse marginale nell'ambito della formazione professionale. L'articolo mostra l'esistenza di studi di carattere storico, antropologico, sociologico, filosofico ed educativo che potrebbero riattivare la ricerca sul problema qui in discussione, facendo riferimento a fasi storiche precedenti, quando l'attenzione verteva sulla segregazione sessuale nel sistema educativo e nel mercato del lavoro. All'inizio dell'articolo la formazione professionale nei paesi nordici viene discussa nell'ottica della problematica dell'appartenenza sessuale soprattutto con riferimento alla Finlandia. In seguito si passa dalla discussione critica di alcuni esempi di tentativi volti a comprendere i fattori legati al sesso di appartenenza all'esposizione di un approccio culturale che permetta di affrontare questi fattori. Infine si esplora la possibilità di un "de-gendering» della formazione professionale. Il messaggio principale dell'articolo consiste nel sottolineare come la proposta di attivare la ricerca sul rapporto tra formazione professionale e fattori determinati dall'appartenenza al sesso sia necessariamente legata ad una valutazione del problema in un contesto più ampio che includa il discorso sui due sessi. 